\title{
Antioxidant effect of vitamin D3 and its relation to salivary proteins and oral health
}

\section{Asmaa Y Thanoon BDS}

Faehaa Azher Al-Mashhadane BDS, MSc, PhD (Assist Prof.)

\author{
Department of Dental Basic Sciences \\ College of Dentistry, University of Mosul
}

Department of Dental Basic Sciences

College of Dentistry, University of Mosul

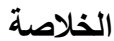

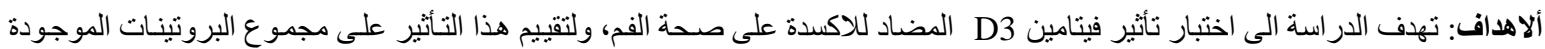

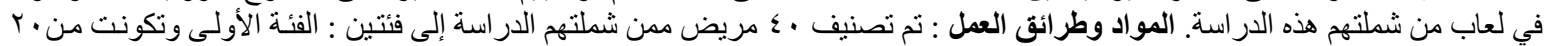

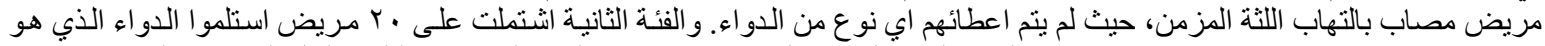

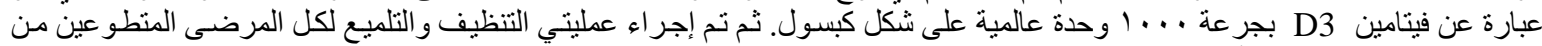

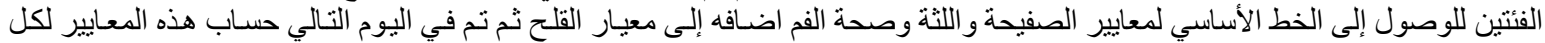

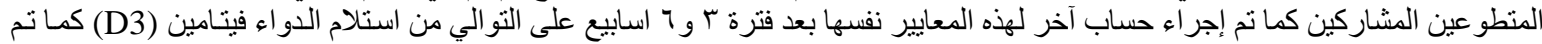

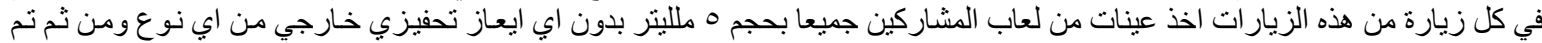

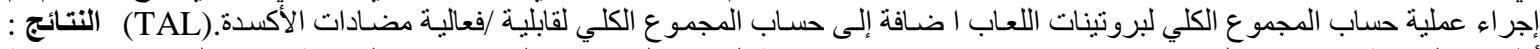

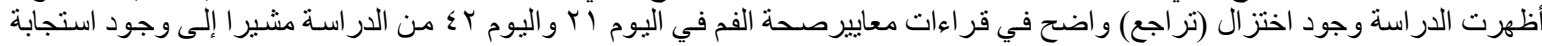

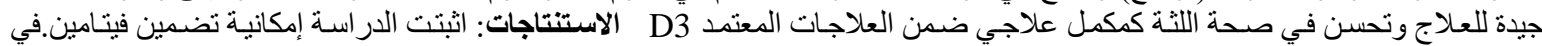

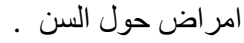

\begin{abstract}
Aims: To investigate the antioxidant effects of vitamin D3 on oral health and to evaluate its effect on total salivary proteins in saliva. Materials and Methods: Forty patients were classified into two groups: Group 1: (20) chronic gingivitis patients, did not receive vitamin D3 (control group), Group 2: (20) chronic gingivitis patients (treatment group), received Vitamin D3 1000IU capsule. Scaling and polishing have been carried out for each volunteer to reach the base line for plaque index, gingival index, oral hygiene index and calculus index. In the next day, these indices were measured for all participants, then measured after 3 weeks then after 6 weeks from treatment. At the same visits, five milliliters of unstimulated saliva were collected for measurement of total salivary proteins and total antioxidant capacity. Results: there were significant reduction in oral health indices in 21st and 42nd days of the study which mean good response to treatment and improvement in gingival health. Conclusion: Vitamin D3 can be a good adjuvant in periodontal therapy
\end{abstract}

Key words: Vitamin D3, Antioxidant, Salivary protein, Oral health.

Thanoon AY., Al-Mashhadane FA Antioxidant effect of vitamin D3 and its relation to salivary proteins and oral health. Al-Rafidain Dent J. 2020 ;20 (1): 114-124.

DOI: $\underline{10.33899 / \text { rden.2020.126781.1024 }}$

Received: 9/3/2020 Sent to Referees:15/3/2020 Accepted for Publication: 3/5/2020

\section{INTRODUCTION}

Gingivitis is an inflammation of the gingiva which is observed as the mildest type of periodontal diseases. The cardinal signs of inflammation involving redness, swelling, bleeding, and exudation and to a lesser extent pain give an indication for the presence of gingivitis ${ }^{(1)}$. Free radicals are non-stable molecules that are created by the body as a response to environment anxiety. Their sources 
can be natural or artificial. They are also classified as endogenous and exogenous. Accumulation of free radicals and inability of the body to remove them efficiently, can result in oxidative stress. Antioxidants can prevent or sluggish damaging effect of free radicals and boost both oral and general health ${ }^{(2)}$. The biochemical changes that occur in gingivitis and periodontitis cause degradation and loss of collagen and are mostly correlated with the liberation of enzymes by host or pathogen, generation of ROS, cytokine release or manipulation of inflammatory mediators, and apoptotic proteins. The high intensity of these molecules is a sign of inflammation; thus, they can be used as biomarkers as well as medicinal goal ${ }^{(3)}$. Higher levels of free radicals as a result of antioxidant shortage has been related to gingival disease. Oxidative process with a high level of reactive oxygen and nitrogen species (ROS and RNS) is noticeable in progression of gingival diseases. This process can result in imbalance leading to tissue damage (4). Oxidative stress biomarkers in saliva reveal pathologies and may tell on the diagnosis and prognosis of diseases ${ }^{(5)}$. A variety of mechanisms against oxidative stress are available in saliva involving glutathione, ascorbic, and uric acid in addition to melatonin. Antioxidant enzymes are present in saliva, protecting oral environment against ROS/RNS as it is the first line defense against insults ${ }^{(6)}$. Vitamin D3 is one of the key regulators of oxidative stress ${ }^{(7)}$. It is synthesized inside the body in the skin when exposed to sunlight ${ }^{(8)}$ Vitamin D3, with its capacity as antioxidant effects ${ }^{(9)}$, could defend the cell from oxidative stress harm by triggering and improving endogenous antioxidant system (10). Considering the limitations of the current study, including the relatively small sample size and the fact that none of the subjects were diagnosed as vitamin D3 deficient, our results showed an important role for VD3 in inducing antioxidant effects and enhancing the improvement in oral health profile in chronic gingivitis patients. The aim of this research is evaluating the antioxidant effect of vitamin D3 on plaque, gingival, oral health, calculus indices of the patients with chronic gingivitis and to determine the relationship with total antioxidant capacity and total salivary protein.

\section{MATERIALS AND METHODS}

This study was randomized clinical trial that was agreed by the scientific committee/department of Dental Basic Science/College, of Dentistry/University of Mosul. The study sample included forty patients, their ages ranged between (20-40 years), recruited from the dental private clinics in Dohuk city. They were classified into two groups:- Group 1 consisted of 20 chronic gingivitis patients, treated by scaling and polishing without Vitamin D3 (control group), Group 2 consisted of 20 chronic gingivitis patients (treatment group) who treated by scaling and polishing and received Vitamin D3 
1000 IU maximum potency, each 1000 IU fast acting liquid soft gel (chicago/USA). The choice of each volunteer depended on inclusion criteria ( healthy individuals, non-pregnant or lactating females, no any drug or supplements, complement of more than 20 teeth, nonsmoking, non-alcoholic).Scaling and polishing had been carried out for each volunteer to reach the base line for plaque index (Silness and Löe, 1964), gingival index (Lőe and Silness, 1963), oral hygiene index and calculus index(Greene and Vermilion, 1960). In the following day, these indices were measured for all participants and measured again after 3 weeks then after 6 weeks from treatment. At the same visits, five milliliters of unstimulated saliva were collected for measurement of total salivary proteins by total protein kit/Biolabo/ France and total antioxidant capacity by TAC Assay
Kit/Elabscience/USA. Statistical Analysis by Microsoft Excel-2010. Independent t-test and One-way Analysis of Variance test (ANOVAtest) with Tukey's Pair-wise comparisons were done.

\section{RESULTS}

In the current study significant differences were observed between treatment and control groups throughout study days. There was a significant reduction in oral health indices in $\mathbf{2 1}^{\text {st }}$ and $\mathbf{4 2}^{\text {nd }}$ days of the study which mean good response to treatment and improvement in gingival health (Tables 1,2 and 3 ). The differences in the oral health indices at the beginning of study might be because of individual variations which could be ignored because of the very clearly significant effect of vitamin $\mathrm{D}$ on these indices after treatment period.

Table (1): Comparison in oral health scores between the two groups at the beginning of study.

\begin{tabular}{cccc}
\hline Oral health scores & $\begin{array}{c}\text { Control group } \\
{[\mathbf{n}=\mathbf{2 0}]} \\
\text { Mean } \pm \text { SD }\end{array}$ & $\begin{array}{c}\text { Treatment group } \\
{[\mathbf{n}=\mathbf{2 0}]} \\
\text { Mean } \pm \text { SD }\end{array}$ & P-value \\
\hline Plaque index & $0.291 \pm 0.317$ & $0.831 \pm 0.457$ & $0.000^{*}$ \\
Gingival index & $0.170 \pm 0.268$ & $0.784 \pm 0.519$ & $0.000^{*}$ \\
Oral hygiene index & $0.606 \pm 0.589$ & $1.361 \pm 0.733$ & $0.001^{*}$ \\
Calculus index & $0.290 \pm 0.277$ & $0.536 \pm 0.355$ & $0.019^{*}$ \\
\hline
\end{tabular}

* Independent T-test of two means was used, $p \leq 0.05$ significant

Table (2): Comparison in oral health scores between the two groups at $21^{\text {st }}$ day of study.

\begin{tabular}{cccc}
\hline Oral health scores & $\begin{array}{c}\text { Control group } \\
{[\mathbf{n = 2 0 ]}} \\
\text { Mean } \pm \text { SD }\end{array}$ & $\begin{array}{c}\text { Treatment group } \\
{[\mathbf{n}=\mathbf{2 0}]} \\
\text { Mean } \pm \text { SD }\end{array}$ & P-value \\
\hline Plaque index & $0.615 \pm 0.407$ & $0.203 \pm 0.240$ & $0.000^{*}$ \\
Gingival index & $0.481 \pm 0.295$ & $0.288 \pm 0.184$ & $0.018^{*}$ \\
Oral hygiene index & $1.095 \pm 0.679$ & $0.457 \pm 0.315$ & $0.000^{*}$ \\
Calculus index & $0.476 \pm 0.332$ & $0.253 \pm 0.138$ & $0.009^{*}$ \\
\hline
\end{tabular}

* Independent T-test of two means was used, $p \leq 0.05$ significant 
Table (3): Comparison in oral health scores between the two groups at $42^{\text {nd }}$ day of study.

\begin{tabular}{cccc}
\hline Oral health scores & $\begin{array}{c}\text { Treatment group } \\
{[\mathbf{n}=\mathbf{2 0}]} \\
\text { Mean } \pm \text { SD }\end{array}$ & $\begin{array}{c}\text { Control group } \\
{[\mathbf{n}=\mathbf{2 0}]} \\
\text { Mean } \pm \text { SD }\end{array}$ & P-value* \\
\hline Plaque index & $0.086 \pm 0.133$ & $0.732 \pm 0.392$ & 0.000 \\
Gingival index & $0.093 \pm 0.115$ & $0.738 \pm 0.344$ & 0.000 \\
Oral hygiene index & $0.185 \pm 0.202$ & $1.324 \pm 0.564$ & 0.000 \\
Calculus index & $0.099 \pm 0.090$ & $0.607 \pm 0.262$ & 0.000 \\
\hline
\end{tabular}

* Independent T-test of two means was used, $p \leq 0.05$ significant

There were significant differences in all control group and treatment groups as shown in oral health score during the study days of both (Tables 4 and 5).

Table (4): Effect of systemic vitamin D treatment on oral health scores during study period.

\begin{tabular}{ccccc}
\hline Oral health scores & $\begin{array}{c}\text { Treatment group } \\
\mathbf{1}^{\text {st }} \text { day } \\
\text { Mean } \pm \text { SD }\end{array}$ & $\begin{array}{c}\mathbf{2 1}^{\text {st }} \text { day } \\
\text { Mean } \pm \text { SD }\end{array}$ & $\begin{array}{c}\mathbf{4 2}^{\text {nd }} \text { day } \\
\mathbf{M e a n}_{\mathbf{S} \text { SD }}\end{array}$ & P-value \\
\hline Plaque index & $0.831 \pm 0.457^{\mathrm{A}}$ & $0.203 \pm 0.240^{\mathrm{B}}$ & $0.086 \pm 0.133^{\mathrm{B}}$ & $\mathbf{0 . 0 0 0}$ \\
Gingival index & $0.784 \pm 0.519^{\mathrm{A}}$ & $0.288 \pm 0.184^{\mathrm{B}}$ & $0.093 \pm 0.115^{\mathrm{B}}$ & $\mathbf{0 . 0 0 0}$ \\
Oral hygiene index & $1.361 \pm 0.733^{\mathrm{A}}$ & $0.457 \pm 0.315^{\mathrm{B}}$ & $0.185 \pm 0.202^{\mathrm{B}}$ & $\mathbf{0 . 0 0 0}$ \\
Calculus index & $0.536 \pm 0.355^{\mathrm{A}}$ & $0.253 \pm 0.138^{\mathrm{B}}$ & $0.099 \pm 0.090^{\mathrm{B}}$ & $\mathbf{0 . 0 0 0}^{*}$ \\
\hline * One-way ANOVA-test with Tukey's Pair wise comparisons was used. Means that do not share a letter are \\
significantly different. $p \leq 0.05$ significant
\end{tabular}

Table (5): Comparison in oral health scores of control group during the study period.

\begin{tabular}{ccccc}
\hline Oral health scores & $\begin{array}{c}\mathbf{1}^{\text {st }} \text { day } \\
\text { Mean } \pm \text { SD }\end{array}$ & $\begin{array}{c}\text { Control group } \\
\mathbf{2 1}^{\text {st }} \text { day } \\
\text { Mean } \pm \text { SD }\end{array}$ & $\begin{array}{c}\mathbf{4 2}^{\text {nd }} \text { day } \\
\text { Mean } \pm \text { SD }^{\text {B }}\end{array}$ & P-value \\
\hline Plaque index & $0.291 \pm 0.317^{\mathrm{B}}$ & $0.615 \pm 0.407^{\mathrm{A}}$ & $0.732 \pm 0.392^{\mathrm{A}}$ & $\mathbf{0 . 0 0 1} *$ \\
Gingival index & $0.170 \pm 0.268^{\mathrm{C}}$ & $0.481 \pm 0.295^{\mathrm{B}}$ & $0.738 \pm 0.344^{\mathrm{A}}$ & $\mathbf{0 . 0 0 0}$ \\
Oral hygiene index & $0.606 \pm 0.589^{\mathrm{B}}$ & $1.095 \pm 0.679^{\mathrm{A}}$ & $1.324 \pm 0.564^{\mathrm{A}}$ & $\mathbf{0 . 0 0 2}$ \\
Calculus index & $0.290 \pm 0.277^{\mathrm{B}}$ & $0.476 \pm 0.332^{\mathrm{AB}}$ & $0.607 \pm 0.262^{\mathrm{A}}$ & $\mathbf{0 . 0 0 4}$ \\
\hline * One-way ANOVA-test with Tukey's Pair wise comparisons was used. Means that do not share a letter are \\
significantly different. $p \leq 0.05$ significant
\end{tabular}

Also in this study no, significant difference was found between means of treatment group and control group in total antioxidant capacity and salivary total protein at the beginning of the study and significant difference was found on the $21^{\text {st }}$ day and on the $42^{\text {nd }}$ day of the study as illustrated in (Tables 6,7 and 8): - 
Table (6): Comparison in salivary levels of TAC, TP between the two groups at the beginning of the study.

\begin{tabular}{cccc}
\hline Salivary parameters & $\begin{array}{c}\text { Control group } \\
{[\mathbf{n}=\mathbf{2 0}]} \\
\text { Mean } \pm \text { SD }\end{array}$ & $\begin{array}{c}\text { Treatment group } \\
{[\mathbf{n}=\mathbf{2 0}]} \\
\text { Mean } \pm \text { SD }\end{array}$ & P-value \\
\hline Salivary TAC $(\mathrm{U} / \mathrm{ml})$ & $5.01 \pm 3.76$ & $6.64 \pm 3.55$ & 0.166 \\
Salivary TP $(\mathrm{g} / \mathrm{dl})$ & $0.62 \pm 0.35$ & $0.59 \pm 0.23$ & 0.752 \\
\hline
\end{tabular}

* Independent T-test of two means was used, $p \leq 0.05$ significant

Table (7): Comparison in salivary levels of TAC, TP between the two groups at $21^{\text {st }}$ day of the study

\begin{tabular}{|c|c|c|c|}
\hline Salivary parameters & $\begin{array}{r}\text { Control group } \\
{[\mathbf{n}=\mathbf{2 0}]} \\
\text { Mean } \pm \text { SD } \\
\end{array}$ & $\begin{array}{r}\text { Treatment group } \\
{[\mathrm{n}=\mathbf{2 0}]} \\
\text { Mean } \pm \text { SD }\end{array}$ & P-value \\
\hline Salivary TAC (U/ml) & $4.78 \pm 3.75$ & $8.32 \pm 4.54$ & $0.011 *$ \\
\hline Salivary TP (g/dl) & $0.69 \pm 0.38$ & $0.51 \pm 0.12$ & 0.039* \\
\hline
\end{tabular}

* Independent T-test of two means was used, $p \leq 0.05$ significant

Table (8): Comparison in salivary levels of TAC, TP between the two groups at $42^{\text {nd }}$ day of the

\begin{tabular}{cccc} 
& \multicolumn{3}{c}{ study. } \\
Salivary parameters & $\begin{array}{c}\text { Control group } \\
{[\mathbf{n}=\mathbf{2 0}]}\end{array}$ & $\begin{array}{c}\text { Treatment group } \\
{[\mathbf{n}=\mathbf{2 0}]}\end{array}$ & P-value \\
& Mean \pm SD & Mean \pm SD & \\
\hline Salivary TAC $(\mathrm{U} / \mathrm{ml})$ & $4.33 \pm 3.46$ & $9.46 \pm 4.82$ & $\mathbf{0 . 0 0 0} *$ \\
Salivary TP $(\mathrm{g} / \mathrm{dl})$ & $0.79 \pm 0.50$ & $0.43 \pm 0.14$ & $\mathbf{0 . 0 0 4} *$ \\
\hline
\end{tabular}

* Independent T-test of two means was used, $\mathrm{p} \leq 0.05$ significant

Comparisons between the means of and $42^{\text {nd }}$ day of the study as illustrated in ( salivary parameters levels as a result of effect Table 9 ), while in the control group during the of Vitamin D3 treatment during the study study period we observed no significant period showed a significant difference in the difference in total antioxidant capacity and means of the total antioxidant capacity and salivary total protein as illustrated in (Table Salivary total protein level between $1^{\text {st }}, 21^{\text {st }} \quad 10$ )

Table (9): Effect of systemic vitamin D treatment on salivary levels of biochemical and antioxidant parameters during the study period.

\begin{tabular}{lcccc}
\hline Salivary parameters & $\begin{array}{c}\mathbf{1}^{\text {st }} \text { day } \\
\text { Mean } \pm \text { SD }\end{array}$ & $\begin{array}{c}\text { Treatment group } \\
\mathbf{2 1}^{\text {st }} \text { day } \\
\text { Mean } \pm \text { SD }\end{array}$ & $\begin{array}{c}\mathbf{4 2}^{\text {nd }} \text { day } \\
\text { Mean } \pm \text { SD }^{\mathrm{A}}\end{array}$ & P-value \\
\hline Salivary TAC $(\mathrm{U} / \mathrm{ml})$ & $6.64 \pm 3.55^{\mathrm{A}}$ & $8.32 \pm 4.54^{\mathrm{A}}$ & $9.46 \pm 4.82^{\mathrm{A}}$ & 0.127 \\
Salivary TP $(\mathrm{g} / \mathrm{dl})$ & $0.59 \pm 0.23^{\mathrm{A}}$ & $0.51 \pm 0.12^{\mathrm{AB}}$ & $0.43 \pm 0.14^{\mathrm{B}}$ & $\mathbf{0 . 0 1 8 *}$ \\
\hline * One-way ANOVA-test with Tukey's Pair wise comparisons was used. Means that do not share a letter are \\
significantly different. $p \leq 0.05$ significant
\end{tabular}


Table (10): Comparison in salivary levels of biochemical and antioxidant parameters of control group during the study period.

\begin{tabular}{lcccr}
\hline Salivary parameters & $\begin{array}{c}\mathbf{1}^{\text {st }} \text { day } \\
\text { Mean } \pm \text { SD }\end{array}$ & $\begin{array}{c}\text { Control group } \\
\mathbf{2 1}^{\text {st }} \text { day } \\
\text { Mean } \pm \text { SD }^{\mathrm{A}}\end{array}$ & $\begin{array}{c}\mathbf{4 2}^{\text {nd }} \text { day } \\
\mathbf{M e a n}^{\mathrm{N}} \mathbf{\text { SD }}\end{array}$ & P-value* \\
\hline Salivary TAC $(\mathrm{U} / \mathrm{ml})$ & $5.01 \pm 3.76^{\mathrm{A}}$ & $4.78 \pm 3.75^{\mathrm{A}}$ & $4.33 \pm 3.46^{\mathrm{A}}$ & 0.837 \\
Salivary TP $(\mathrm{g} / \mathrm{dl})$ & $0.62 \pm 0.35^{\mathrm{A}}$ & $0.69 \pm 0.38^{\mathrm{A}}$ & $0.79 \pm 0.50^{\mathrm{A}}$ & 0.438 \\
\hline * One-way ANOVA-test with Tukey's Pair wise comparisons was used. Means that do not share a letter are \\
significantly different. $p \leq 0.05$ significant
\end{tabular}

\section{DISCUSSION}

Studies pointed out that adequate vitamin D levels may improve periodontal health $(11,12,13)$. The present study focused on chronic gingivitis as one of the most common inflammatory disease. The anti-inflammatory effect of vitamin D is depending on dose ${ }^{(14)}$. In our study a dose of 1000IU fast acting liquid soft gel of VD3 at has been used, the safety of VD3 have been taken into consideration at dose selection. The margin of safety for VD3 consumption for adult are ten times greater than recommended dose. The food and Nutrition Board of USA has been recommended 2000 IU/day as the safe upper limit of vitamin D. It can be safely supplemented orally in dose ranging from 500-2000 IU for 2 to 3 months to get the desired result for patients with inflammatory conditions regardless its serum level ${ }^{(14)}$. Tooth brushing is effective in reducing levels of dental plaque; thus, it is the reference technique for control of plaque. Studies showed that after tooth brushing, a significant reduction in the plaque index was observed and considered to be the baseline plaque index. In agreement with others, in this study scaling and polishing have been carried out for each volunteer to reach the base line. In the next day, the plaque, gingival, calculus and oral hygiene indices score for all participants were measured before treatment as a base line data ${ }^{(15,16)}$. The differences in the oral health indices at the beginning of study might be because of individual variations which could be ignored because of the very clearly significant effect of vitamin $\mathrm{D}$ on these indices after treatment period. Saliva has been confirmed to be of grand usefulness for finding out biomarkers of oral diseases ${ }^{(17)}$. Salivary gland hypofunction lead to greater risks of oral dysfunctions, histopathology's of oral cavity are linked with oxidative stress ${ }^{(18,19)}$ Lipid peroxidation, protein oxidation and DNA damage markers brought about by reactive oxygen species and can be measured in saliva. Gingivitis could be resulted from an excessive release of reactive oxygen species due to inflammation or by the lack of salivary antioxidants ${ }^{(19,14)}$. VD3 as antioxidant agent could promote oral health and also partly protect the cell from oxidative stress damage by activating endogenous antioxidant system $^{(20) .}$ It is correlated with decrease in the 
severity of gingivitis throughout immunomodulatory, anti-inflammatory and antibacterial properties ${ }^{(21)}$, this activity of Vitamin D3 is due to its association with LL37, which is known as cathelicidins and they are a group of antimicrobial peptides (22). cathelicidins demonstrate a chemotactic and immunostimulatory/-modulatory effect ${ }^{(23)}$. it interacts with biofilms, bacteria and host cell and affecting their oxidative effects and other damaging actions ${ }^{(24)}$. The current study noticed significant differences between treatment and control groups throughout the study days as there were significant reductions in oral health indices in $\mathbf{2 1}^{\text {st }}$ and $\mathbf{4 2}^{\text {nd }}$ days of the study indicating a good response to the treatment and improvement in the gingival health. Total antioxidant capacity (TAC) is the estimated number of free radicals scavenged and used to estimate the antioxidant capacity of biological samples (25). Comparisons between the means of salivary parameters levels as a result of effect of Vitamin D3 treatment during the study period showed a significant rise in the means of the total antioxidant capacity on $21^{\text {st }}$ and $42^{\text {nd of }}$ the study period proving potential for pro and anti-oxidative effects of vitamin D3 ${ }^{(26)}$. This action of Vitamin D3 can be explained by the fact that vitamins are essential organic compounds that catalyze metabolic reactions as well as they also function as electron donors' antioxidants or transcription effectors (27). Nuclear factor erythroid 2-related factor 2 (NrF2), control antioxidant expression is downregulated in periodontitis patients. Recent confirmations indicated that $\mathrm{NrF} 2$ plays a protective function in numerous diseases, being periodontitis as one of them. Vitamin D3 improve cytoprotective effects such as decreased inflammatory signaling and oxidative damage in tissues through up regulation of $\mathrm{NrF} 2$-associated antioxidant and detoxification enzymes, for that reason, $\mathrm{NrF} 2$ activation may be a valuable adjuvant in therapeutic defense against periodontitis ${ }^{(28)}$. Inhibition of oxidative stress is related to $\mathrm{NrF} 2$ in periodontal tissue (29). Vitamin D3 has an upregulating nuclear factor (Nrf2) that is reducing reactive oxygen species decreasing DNA damage, increasing cell proliferation, and reducing cellular senescence ${ }^{(30)}$. Another cause of elevation of TAC in this study can be explained by the fact that BH4 [tetrahydrobiopterin] which is an adjuvant factor for tyrosine hydroxylase and tryptophan hydroxylase, these enzymes are crucial for dopamine, norepinephrine, and serotonin the biosynthesis. It has been known that $\mathrm{BH} 4$ is a labile molecule and easily oxidized $^{(31)}$. BH4 reacts with molecular oxygen to form an active oxygen intermediate ${ }^{(32)}$. The role of the cofactor tetrahydrobiopterin $(\mathrm{BH} 4)$ in NO production is well established ${ }^{(33)}$ The results of present study can be explained by fact that vitamin D3 could regulate cell death throughout action on relationship between autophagy and apoptosis. This outcome is attained by inhibiting superoxide anion generation, keeping up mitochondria function 
and cell viability, activating survival kinases, and more construction of nitric oxide (NO) ${ }^{(34)}$ which is a highly reactive molecule, formed at different locations in the body involving diverse enzymatic and non-enzymatic pathways. All this helps NO in its (patho)physiological roles ${ }^{(34)}$. also, in this study no, significant difference was found between means of treatment group and control group in salivary total protein at the beginning of the study period whereas a significant difference was found on $21^{\text {st }}$ and $42^{\text {nd }}$ days of the study period (decrease total salivary protein with vitamin D3 treatment). Proteins of saliva can work together with oral bacteria in different manners. Lysozymes, interleukins, and lactotransferrin (LTF) can encourage bacterial adherence and cell aggregation while others like beta defensins, produce direct antibacterial effects. Studies of salivary proteins and peptides signified that these proteins have valuable investigative ability in numerous clinical circumstances, which may permit the progress of preventive program and individual management ${ }^{(35)}$. Increased oral neutrophil recruitment and salivary cytoprotective proteins increased progressively during inflammation and decreased in resolution (36). According to this study, the use of vitamin D3 can be a good adjuvant in periodontal therapy throughout modulating oxidative stress of gingiva as well as its antioxidant action may guide the preservation of periodontal health and decrease inflammatory intensity ${ }^{(37)}$. In occurrences of inflammation a number of changes in salivary protein composition have been observed, often these observations have been made in chronic inflammation ${ }^{(38)}$.

\section{CONCLUSSION}

VD3 can increase the level of total antioxidant capacity in saliva, so it enhances anti-oxidant effect which help to improve gingival health. Also it can decrease the level of total salivary proteins by oral health improvement.

\section{Acknowledgment}

Author are greatly appreciative to the University of Mosul / College of Dentistry for their kind assessment to reach best quality of this research.

\section{REFERENCES}

1-Bringhurst F. R., Demay M. B., Krane S. M., Kronenberg H. M. Bone and mineral metabolism in health and disease. In: editors. Harrison's principles of internal medicine. (2015). Vol. 2. McGraw Hill; pp. 2454-2465. [Google Scholar]

2-Mamta P, Kshipra M, Garry D, Satinder K B. Exploitation of Agro-Industrial Wastes to Produce Low-Cost Microbial Surfactants. Antioxidant Chapter. (2014). pp:117-138.

3-Naveen $\quad R \quad B$, Garima S, Vandana $\mathrm{M}$. Evaluation of total antioxidant level of saliva in modulation of caries occurrence 
and progression in children ORIGINAL ARTICLE. (2016). 34 (3): 227-232

4- Micaele M L C, Nathallia N D, Priscila C N,1 Marcela B, Nathalia C F F, Carlos F, et al. Antioxidants as Adjuvants in Periodontitis Treatment. A Systematic Review and Meta-Analysis. (2019). ID 9187978 | 24 pages. Volume Article

5- Wang, J., Schipper, H. M., Velly, A. M., Mohit, S., \& Gornitsky, M. Salivary biomarkers of oxidative stress: A critical review. Free Radical Biology and Medicine. (2015). 85:95-104.

6- Tóthová L, Natália K, Tomáš Č, Peter C. Salivary markers of oxidative stress in oral diseases. Oral Biol Cranio-fac Res. (2016). Jan-Apr; 6(1): 66-75.

- 7- Michele D R, Lucia M, Anna N, Cristina S, Clorinda M, Piero P, et al. Vitamin D3: an ever green molecule. Frontiers in Bioscience. (2013) S5, P:247-260

8-AUBMC, World Health Organization and Food and Agriculture Organization of the United Nations 2004, Vitamin and mineral requirements in human nutrition.

9-Kochwvar I. E., Taylor C. R., Krutmann J. Fundamentals of cutaneous photobiology and photo-immunology. In: Wolff K., Goldsmith L. A., Katz S. I., et al., editors. in Fitzpatrick's Dermatology in General Medicine. (2012). Vol. 2. New York, NY, USA: McGraw-Hill; pp. 1031-1048. [Google Scholar
10- AmenehT,Maryam S,Hamideh G S, Mohammad R, Parizadehb R S, Maryam E z, Fatemeh E,Tavallaieb G A,Fernsf M G. Evaluation of the serum prooxidantantioxidant balance before and after vitamin D supplementation in adolescent Iranian girls. Author links open overlay panel: (2018).

11-Grant WB, \& Boucher BJ. Are Hill's criteria for causality satisfied for vitamin D and periodontal disease? Dermatoendocrinology. (2010). 2: 30-36.

12-Bashutski JD, Eber RM, Kinney JS, Benavides E, Maitra S, Braun TM., et al.. The impact of vitamin $\mathrm{D}$ status on periodontal surgery outcomes. Journal of Dental Research. (2011). 90 (8), 1007-12.

13-Alshouibi, E. N., Kaye, E. K., Cabral, H. J., Leone, C. W., \& Garcia, R. I. Vitamin D and periodontal health in older men. Journal of Dental Research, (2013). 92, 689-693.

14-Hiremath VP, Rao CB, Naiak V, Prasad KVV., Anti-inflammatory effect of vitamin D on gingivitis: A dose response randomised controlled trial. Oral Health Prev Dent. (4-May-2013) 11 (1), 61-9.

15-Lynch MC, Cortelli SC, McGuire JA, Zhang J, Ricci-Nittel D, Mordas CJ et al. The effects of essential oil mouthrinses with or without alcohol on plaque and gingivitis: a randomized controlled clinical 
study. BMC Oral Health. (2018).18(6).

16-Rubido S, Caballero LG, Abeleira MT, Limeres J,García M, and Diz PEffect of chewing an apple on dental plaque removal and on salivary bacterial viability. PLoS One. (2018). 13(7): e0199812..

17- J.A. Loo, W. Yan, P. Ramachandran, D.T. Wong, Comparative Human Salivary and Plasma Proteomes.Dent Res. .(2010). Vol;89(10) :1016-23.

18- Lynge PAM, Belstrøm D . The role of natural salivary defenses in maintaining a healthy oral microbiota. J Dent. (2019).

Jan;80 Suppl 1: S3-S12.

19- Tóthová, L., Kamodyová, N., Červenka, T., \& Celec, P. Salivary markers of oxidative stress in oral diseases. Frontiers in Cellular and Infection Microbiology, (2015). 5.

20-Zhou J, Wang F, Ma Y, Wei F. Vitamin D3 Contributes to Enhanced Osteogenic Differentiation of MSCs Under Oxidative Stress Condition via Activating the Endogenous Antioxidant System. Osteoporosis Int. (2018). 29 (8): 19171926.

21-Khammissa RAG, Ballyram R, Jadwat Y, Fourie J, Lemmer J, Feller L.Vitamin D Deficiency as It Relates to Oral Immunity and Chronic Periodontitis.Int J Dent. (2018). 1:7315797.
22-Johanna G, Karin R, pernilla L H. Vitamin D status and dental caries in healthy swedish children. Nutrition Journal . (2018). 17(1) ·

23-Vandamme D, Landuyt B, Luyten W, Schoofs L . A comprehensive summary of LL-37, factotum human cathelicidin peptide. view in Cellular Immunology . (2012) . 280(1):22-35 .

24-. Allen J .D, Monique L V H .the human cathelicidin antimicrobial peptide LL-37 as a potential treatment for. polymicrobial infected wounds. National Library of Medicine. (2013) .3(4): 143

25-Rubio C P, osefa H, Silvia M, Asta T \& José J.Creon -Spectrophotometric assays for total antioxidant capacity (TAC) in dog serum: an update BMC Veterinary Research . (2016).12(166).

26- Timar A. Evaluation of the serum prooxidant - antioxidant balance before and after Vitamin D supplementation in adolescent Iranian girls. Advances in Medical Sciences. (2019). 64(1):174-180. 27- Zohoori FV, Duckworth RM. The Impact of Nutrition and Diet on Oral Health. Monogr Oral Sci. (2020) Basel, Karger. 28: IX-X

28-Chiu, A. V., Saigh, M. A., McCulloch, C. A., \& Glogauer, M. The Role of NrF2 in the Regulation of Periodontal Health and 
Disease. Journal of Dental Research, (2017).96(9), 975-983.

29-Li, X., Sun, X., Zhang, X., Mao, Y., Ji, Y., Shi, L., ... Huang, S. by Enhanced Oxidative Damage and Nrf2 Downregulation Contribute to the Aggravation of Periodontitis Diabetes Mellitus. Oxidative Medicine and Cellular Longevity. (2018).1-11.

30-Lulu C, Renlei Y, Wanxin Q, Wei Z, Jie C, Li M, David G, Dengshun M. 1,25Dihydroxy-vitamin D exerts an antiaging role by activation of Nrf2-antioxidant signaling and inactivation of $\mathrm{p} 16 / \mathrm{p} 53$ senescence signaling . Aging Cell. (2019).18(3): e12951.

31-Takeshita N, Kawade N, Suzuki W, Hara S, Horio F, Ichinose H.Deficiency of ascorbic acid decreases the contents of tetrahydrobiopterin in the liver and the brain of ODS rats. Article in Neuroscience Letters.(2020). 715:134656

32-Anna V B , Luis O R, MD, MS, FAAP, FACMG more. BH4 Deficiency .Drugs \& Diseases > Pediatrics: Genetics and Metabolic Disease. (2018). med scape.

33-Uberti F, Lattuada D, Morsanuto V, Nava U, Bolis G, Vacca G, Squarzanti DF, Cisari C, Molinari C.Vitamin D protects human endothelial cells from oxidative stress through the autophagic and survival pathways. J Clin Endocrinol Metab. (2014) $.99(4): 1367-74$
34-Yvette C. Luiking, Ph D, Mariëlle P.K.J. Engelen, $\mathrm{PhD}$, Nicolaas E.P. Deutz. REGULATION OF NITRIC OXIDE PRODUCTION IN HEALTH AND DISEASE. Current Opinion in Clinical Nutrition and Metabolic Care: (2010). 13 (1) :97-104.

35-Lips A, Antunes LS, Antunes LA, Pintor AVB, Santos DABD, Bachinski R, Küchler EC, Alves GG. Salivary protein polymorphisms and risk of dental caries. a systematic review. Braz Oral Res. (2017). 5;31: 41.

36-Aboodi GM, Sima C, Moffa EB, Crosara KT, Xiao Y, Siqueira WL, Glogauer M. salivary cyto protein in inflammation and resolution during experimental gingivitis. A pilot study, Front Cell Infect Microbiol. (2016). 5;5: 92.

37-Gordon B P. The function of salivary proteins and the regulation of their secretion by salivary glands. BiologyPublished 1998

38- Castro, M. M. L., Duarte, N. N., Nascimento, P. C., Magno, M. B., Fagundes, N. C. F., Flores-Mir, C., ... Lima, R. R.. Antioxidants as Adjuvants in Periodontitis Treatment: A Systematic Review and Meta-Analysis. Oxidative Medicine and Cellular Longevity, 2019, 1 24. 